\title{
Go protein subunit Go $\alpha$ and the secretory process of the natriuretic peptide hormones ANF and BNP
}

\author{
Cassandra Roeske', Amy Martinuk', Asna Choudhry ${ }^{1}$, Geoffrey N Hendy ${ }^{3}$, \\ Michael Gollob ${ }^{4}$, Qiuji Li ${ }^{4}$, Tina Georgalis ${ }^{1}$ and Adolfo J de Bold ${ }^{1,2}$ \\ ${ }^{1}$ Cardiovascular Endocrinology Laboratory, University of Ottawa Heart Institute, 40 Ruskin Street, Ottawa, \\ Ontario, Canada K1Y 4W7 \\ ${ }^{2}$ Department of Pathology and Laboratory Medicine, Faculty of Medicine, University of Ottawa, Ottawa, \\ Ontario, Canada K1H 8M5 \\ ${ }^{3}$ Experimental Therapeutics and Metabolism, McGill University Health Centre-Research Institute, and \\ Departments of Medicine, Physiology and Human Genetics, McGill University, Montreal, Quebec, Canada \\ ${ }^{4}$ Toronto General Hospital, 200 Elizabeth Street, Toronto, Ontario, Canada M5G 2C4
}

Correspondence should be addressed

to A J de Bold

Email

adebold@bell.net

\begin{abstract}
Expression of the G protein subunit Go $\alpha$ has been shown to be prominent in the atria of the rat heart and to be significantly associated with atrial natriuretic factor (ANF)-containing atrial-specific secretory granules by immunocytochemistry. In addition, differential expression profile analysis using oligonucleotide arrays has shown that the Go $\alpha$ isoform 1 (Go $\alpha 1$ ) is 2.3-fold more abundant in the atria than it is in the ventricles. In the present report, we show protein-protein interaction between Go $\alpha$ and ANF by yeast two-hybrid and by immunoprecipitation. A cardiac conditional Go $\alpha$ knockout model developed for the present study showed a $90 \%$ decrease in Go $\alpha$ expression and decreased atrial expression and ANF and brain natriuretic peptides (BNP) content. Expression of chromogranin A, a specific atrial granule core constituent, was not affected. Morphometric assessment of atrial tissue showed a very significant decrease in atrial-specific granule density as well as granule core electron density. Atrial electrical activity was not affected. The results obtained are compatible with the suggestion that Go $\alpha$ plays a role in ANF sorting during intracellular vectorial transport and with the presence of a mechanism that preserves the molar relationship between cellular ANF and BNP stores in the face of the decreased production of these hormones.
\end{abstract}
Key Words
- endocrine heart
- ANF
- G proteins
- hormone storage
- hormone secretion

\section{Introduction}

At least three types of secretory mechanisms for the natriuretic peptides (NP) atrial natriuretic factor (ANF, ANP) and the brain natriuretic peptides (BNP) operate in atrial cardiomyocytes, and they include constitutive, regulated, and constitutive-like secretions (Ogawa et al. 1999). The stimulated secretion of NP involves G proteinassociated mechanisms. Neuroendocrine agonists, such as endothelin-1 (ET-1), angiotensin II, and catecholamines, are known to utilize receptors coupled to effectors by $\mathrm{Gq}$ proteins. On the other hand, ANF secretion promoted through atrial muscle stretch (stretch-secretion coupling) (Kuroski de Bold \& de Bold 1991) utilizes a mechanism that is inhibited by pertussis toxin (PTX), a specific inhibitor of the Gi/o family of $G$ proteins (Bensimon et al. 2004, McGrath \& de Bold 2005). The stimulation of ANF secretion by ET-1 has been shown to proceed unimpaired in the atria from

Published by Bioscientifica Ltd. 
PTX-treated rats, which shows that the Gq/11 and Gi/o pathways of signaling during stimulated ANF secretion are functionally independent and may function in parallel (Bensimon et al. 2004). This dual stimulatory pathway would be expected to be operational in hemodynamic overload conditions, such as chronic congestive heart failure, in which neuroendocrine activation coexists with increased intracardiac pressures that lead to increased atrial muscle stretch. Both agonist-mediated and stretch-mediated secretion of NP from atrial cardiomyocytes cause the release of newly transported peptides in preference over the older NP pool, as has been revealed by double-label pulse-chase studies (Mangat \& de Bold 1993, Ogawa et al. 1999).

There is scant information regarding the details of $G$ protein participation in agonist-promoted NP secretion. Expression of the $G$ protein subunit Go $\alpha$ is prominent in the atria and is significantly associated with ANFcontaining secretory granules, as has been shown by immunocytochemistry, and it is virtually absent in ventricular cardiomyocytes (Wolf et al. 1998, Bensimon et al. 2004). Differential expression profile analysis between rat atria and ventricles using oligonucleotide arrays revealed that the G protein Go $\alpha$ isoform 1 (Go $\alpha 1$ ) is 2.3 -fold more abundantly expressed in the atria than in the ventricles (McGrath \& de Bold 2009).

In the present report, we further explore the association between Go $\alpha$ and atrial secretory function by assessing Go $\alpha$ protein-protein interactions in atrial muscle using yeast two-hybrid screening and the biochemistry and morphology of atrial cardiomyocyte phenotype in transgenic mice carrying a conditional cardiac Go $\alpha$ knockout. In the latter, we studied the expression of secretory granule components, including ANF, BNP, and chromogranin A (ChgA), as well as ANF processing and the effect of the knockout on ultrastructure and on cardiac electrophysiological activity.

\section{Materials and methods}

\section{Experimental animals}

All of the experiments involving animals were approved by the Animal Care Committee of the University of Ottawa and were carried out according to the Canadian Council on Animal Care Guide to the Care and Use of Experimental Animals.

\section{Conditional Go $\alpha$ knockout}

Go $\alpha$-floxed mice with loxP sites flanking exons 5 and 6, which are common to both isoforms Go $\alpha_{\mathrm{A}}$ and $\mathrm{Go} \alpha_{\mathrm{B}}$ (also
Go $\alpha 1$ and Go $\alpha 2$ ) were generously provided by Dr Lutz Birnbaumer. NIEHS mice, strain 129SvEv, were used. The process for disrupting of this gene has been previously described (Chamero et al. 2011). $\alpha$-myosin-heavy chain $(\alpha-\mathrm{MHC})$-Cre mice were purchased from the Jackson Laboratory (Bar Harbor, ME, USA), strain name B6.FVB$\mathrm{Tg}$ (Myh6-cre)2182Mds/J, strain no. 011038. Expression of Cre, which is driven by the $\alpha$-MHC (cardiac-specific) promoter, induces more than $90 \%$ recombination in cardiac muscle cells when two loxP sites are present.

Male mice that were obtained after a standard breeding scheme for F2 generation were used. Controls were C57BL/6 x129SvEv males.

\section{Cre/lox generation}

Standard Cre/lox tissue-specific breeding protocol was followed. Briefly, breeding a homozygous Go $\alpha$-floxed mouse to a hemizygous $\alpha$-MHC-Cre mouse produces $50 \%$ offspring that are heterozygous for the floxed allele that has been recombined in the presence of Cre to delete this allele in the heart $(\mathrm{cGo} \alpha+/-)$. Breeding a homozygous Go $\alpha$-floxed mouse to a hemizygous $\alpha$-MHC-Cre produces $25 \%$ offspring that are homozygous for the floxed alleles that have both been recombined in the presence of Cre to delete both alleles in the heart (cGo $\alpha-/-)$.

All of the genotypes were produced in Mendelian frequencies. Table 1 shows all of the genotypes obtained from the Cre/lox mating scheme and their respective transgenic titles and genotypes. The homozygous floxed mouse Go $\alpha \mathrm{flx} / \mathrm{flx}$ was used as the control mouse (Zhao et al. 2010).

\section{Genotyping and primers}

At 21 days of age, a $0.1 \mathrm{~cm}$ tail clipping was taken from each mouse. DNA extraction was performed using a REDExtract-N-Amp Tissue PCR Kit (XNAT, SigmaAldrich), and subsequent PCR amplification was performed using a REDExtract-N-Amp PCR Mix (XNAT, Sigma-Aldrich) in an Eppendorf Mastercycler Thermal Cycler (Eppendorf, Missisauga, Ontario, Canada). PCR parameters for genotyping the Go $\alpha$-floxed alleles, the Cre alleles, and control alleles are listed in Tables 2 and 3 . Oligonucleotide sequences for genotyping are listed in Table 2. Amplicons were run on a $1 \%$ agarose gel using a $1 \mathrm{~kb}$ ladder (G571A, Promega) for calibration purposes, except for Cre products, which were run on a $1.5 \%$ agarose gel using a $50 \mathrm{bp}$ ladder to calibrate the migrations of the

Published by Bioscientifica Ltd. 
Table 1 Genotypes obtained from F1 and F2 Cre/lox generation breeding scheme

\begin{tabular}{|c|c|}
\hline Go $\alpha$ genotype $^{a}$ & Transgenic title \\
\hline $\begin{array}{l}\text { C (conditional) Go } \alpha-I- \\
\mathrm{cGo} \alpha+/- \\
\mathrm{cGo} \alpha+/+\end{array}$ & $\begin{array}{l}\text { Homozygous conditional knockout } \\
\text { Heterozygous conditional knockout } \\
\text { Homozygous floxed control } \\
\text { Heterozygous floxed } \\
\text { Hemizygous Cre } \\
\text { WT }\end{array}$ \\
\hline
\end{tabular}

Full genotype
$\alpha \mathrm{MHC} C^{\mathrm{Cre}} ; \mathrm{Go} \alpha^{\mathrm{Flx} / \mathrm{Flx}}$
$\alpha \mathrm{MHC} \mathrm{C}^{\mathrm{Cre}} ; \mathrm{Go} \alpha^{\mathrm{Flx} / \mathrm{Wt}}$
$\mathrm{Wt} ; \mathrm{Go} \alpha^{\mathrm{Fl} / \mathrm{Flx}}$
$\mathrm{Wt} ; \mathrm{Go} \alpha^{\mathrm{Fl} x / \mathrm{Wt}}$
$\alpha \mathrm{MHC} \mathrm{Cre}^{\mathrm{Cre}} ; \mathrm{Go} \alpha^{\mathrm{Wt} / \mathrm{Wt}}$
$\mathrm{Wt} ; \mathrm{Go} \alpha^{\mathrm{Wt} / \mathrm{Wt}}$

aOnly the first and third genotypes were compared in the present report.

amplicons (10488, Invitrogen). Primers were commercially synthesized by Operon (www.operon.com/).

\section{Chromogranin A knockout mice}

The generation of the Chga knockout mice has been previously reported (Hendy et al. 2006). Controls were Balb/c. Only male knockout and control mice were used.

\section{Yeast two-hybrid}

The methodology followed for yeast two-hybrid screening has been previously published (Ogawa et al. 2009). Briefly, poly (A) + RNA was isolated from rat atria using the Absolutely mRNA Purification Kit (Stratagene, Agilent Technologies, La Jolla, CA, USA). An atrial tissue library was constructed using a HybriZAP 2.1 XR Library Construction Kit and a HybriZAP 2.1 XR cDNA Synthesis Kit (Stratagene). cDNA inserts were cloned into the HybriZAP 2.1 vector, and the HybriZAP 2.1 library was converted to the pAD-GAL-4-2.1 library (target protein) by mass excision, as described in the manufacturer's instructions for the HybriZAP 2.1 XR Library Construction Kit and the HybrizAP 2.1 XR cDNA Synthesis Kit. DNA encoding amino acids 1-354 of the activated Q205L mutant of rat Go 1 (kindly provided by Brad Denker, Harvard Medical School, Cambridge, MA, USA) was cloned into the pBD-GAL4 Cam phagemid 'bait' vector (Stratagene) and cotransformed with $\sim 20 \times 10^{6}$ atrial cDNA clones contained within the pAD-GAL-4-2.1 'prey' vector using yeast strain YRG-2 (Stratagene). Plasmid recovered from 92 positive clones that grew on triple dropout (-Trp/ -Leu/-His) plates were sequenced. The yeast transformation was performed by the S. C. Easy Comp Transformation Kit (Invitrogen) according to the manufacturer's instructions.

\section{Plasma collection}

Trunk blood was collected in $1.5 \mathrm{ml}$ tubes that had previously been rinsed with 15\% EDTA and centrifuged at $2000 \boldsymbol{g}$ for $20 \mathrm{~min}$ at $4{ }^{\circ} \mathrm{C}$, and the plasma was stored at $-80^{\circ} \mathrm{C}$. The plasma samples were acidified with $100 \mu \mathrm{l}$ $0.1 \mathrm{M} \mathrm{HCl} / \mathrm{ml}$ plasma and were passed three times through Sep-Pak C18 cartridges (Millipore-Waters Corp., Milford, MA, USA) pre-wetted with $5 \mathrm{ml} \mathrm{80 \%} \mathrm{acetonitrile} \mathrm{(ACN)} \mathrm{in}$ $0.1 \%$ trifluoroacetic acid (TFA), followed by $20 \mathrm{ml}$ of $0.1 \%$ TFA. After processing, the cartridges that had received the plasmas were then eluted with $3 \mathrm{ml} 80 \% \mathrm{ACN}$ in $0.1 \%$ TFA. Samples were then freeze-dried and reconstituted in $220 \mu \mathrm{l}$ of RIA buffer $(0.1 \mathrm{M}$ sodium phosphate, $0.05 \mathrm{M}$ $\mathrm{NaCl}, 0.01 \%$ sodium azide, $0.1 \%$ Triton $\mathrm{X}-100$, and $0.1 \%$ heat-treated BSA).

\section{RNA extraction and RT}

Atrial appendages and the apical portions of the ventricles were immersed in 1 and $3 \mathrm{ml}$ respectively of TRIzol Reagent (Invitrogen) immediately after removal and were stored at

Table 2 Primers used for genotyping

\begin{tabular}{l} 
Name \\
\hline Go $\alpha$-floxed \\
$\alpha-M H C-C r e$ \\
TCR- $\alpha$ control \\
ANF WT \\
ANF mutant \\
ChgA WT \\
ChgA mutant
\end{tabular}

Forward primer $\left(5^{\prime}-3^{\prime}\right)$

AAGAATAGAACCTAGGACTGGAGG

ATGACAGACAGATCCCTCCTATCTCC

CAAATGTTGCTTGTCTGGTG

CTGTCCAACACAGATCTGATG

CTGTCCAACACAGATCTGATG

GATGAAGTGCGTCCTGGAAGTCATCTCCGA

ACAACAGACAATCGGCTGCTC

\begin{tabular}{l} 
Reverse primer $\left(\mathbf{5}^{\prime} \mathbf{-} \mathbf{3}^{\prime} \mathbf{)}\right.$ \\
\hline GCAGACAAGTGAACAAGTGAAACCC \\
CTCATCACTCGTTGCATCATCGAC \\
GTCAGTCGAGTGCACAGTTT \\
CTGTTGCAGCCTAGTCCACT \\
CCTTCTATCGCCTTCTTGACG \\
CTTGGAGAGCCAGGTCTTGAAGTTCCTTCA \\
CCATGGGTCACGACGAGATC
\end{tabular}

http://jme.endocrinology-journals.org DOI: 10.1530/JME-15-0081 (c) 2015 Society for Endocrinology Printed in Great Britain
Published by Bioscientifica Ltd 
Table 3 Oligonucleotide primer sequences for quantitative real-time PCR

\begin{tabular}{l} 
Name \\
\hline BNP \\
Go $\alpha$ \\
ANF \\
G6PD \\
\hline
\end{tabular}

\begin{tabular}{l} 
Forward primer $\left(\mathbf{5}^{\prime}-\mathbf{3}^{\prime}\right)$ \\
\hline CAGCTCTTGAAGGACCAAGG \\
TGCACGAGTCTCTCATGCTCT \\
GCCGGTAGAAGATGAGGTCA \\
CCAGCCTCCTACAAGCACCTCA
\end{tabular}

Reverse primer $\left(5^{\prime}-3^{\prime}\right)$

AGACCCAGGCAGAGTCAGAA

AGATGGTCAAGGGTGACTTCT GGGCTCCAATCCTGTCAATC AATAGCCCCACGACCCTCAGTA $-80^{\circ} \mathrm{C}$. Further processing was done by homogenizing using a Polytron (PT10-35, Kinematica, Inc., Bohemia, NY, USA) at 70\% power for 15-20 s and completing total RNA extraction according to the manufacturer's instructions. The quality of the RNA extracted was assessed using a 2100 Bioanalyzer (Agilent Technologies) with an RNA 6000 Nano Kit (Agilent Technologies). cDNA was synthesized by a Transcriptor First Strand cDNA Synthesis Kit (Roche Applied Science) following the manufacturer's instructions using $1 \mu \mathrm{g}$ of total RNA.

\section{Quantitative real-time PCR}

Quantitative real-time RT-PCR was performed using LightCycler 480 SYBR Green I Master Mix and analyzed using the LightCycler 480 SW 1.5 quantification software (Roche Applied Science) according to the manufacturer's instructions.

Primer nucleotide sequences were as published (Niu et al. 2005) or obtained from the literature and validated using Primer3 Input version 0.4.0 (http://frodo.wi.mit. edu). Primer nucleotide sequences are listed in Table 3. Glucose-6-phosphate dehydrogenase (G6PD) was used as the reference gene, and concentration ratios were normalized to the calibrator and corrected using primer efficiency. Analyses of each gene of interest were performed in triplicate. A standard curve was constructed in triplicate for each primer pair.

\section{Western blot}

Freshly obtained tissues were placed in RIPA buffer (150 mM NaCl, 50 mM Tris- $\mathrm{mCl}$ (pH 7.4), 1 mM EDTA (pH 8.0), 1\% Nonidet P-40, and 0.5\% sodium deoxycholate) and 1:100 dilution of protease inhibitor cocktail (P8340, Sigma) and stored at $-80^{\circ} \mathrm{C}$. The tissues were then homogenized using a Polytron at 70\% power for 15-20 s, and the homogenate was centrifuged at $9300 \boldsymbol{g}$ for $10 \mathrm{~min}$ at $4{ }^{\circ} \mathrm{C}$. Protein quantification in the supernatant was determined using a Pierce BCA Protein Assay Kit (Pierce, Thermo Scientific, Ottawa, Ontario, Canada).
For electrophoretic separation, the samples were prepared by adding $7 \mu \mathrm{g}$ of atrial protein to $3 \mathrm{X}$ Blue loading dye (7722, Cell Signaling Technology, Danvers, MA, USA) and 10\% dithiothreitol (DTT) and boiling for 2 min at $95{ }^{\circ} \mathrm{C}$. A $30 \mu \mathrm{l}$ sample was loaded into a $10 \%$ MiniPROTEAN TGX precast gel (Bio-Rad Laboratories, Inc.) and run at $200 \mathrm{~V}$ for $45 \mathrm{~min}$, along with a biotinylated ladder (Precision-Plus Protein Western C, Bio-Rad Laboratories, Inc.) and mouse brain extract (sc-2253, Santa Cruz Biotechnology, Inc.). The gel was transferred to a $0.45 \mu \mathrm{m}$ PVDF membrane (Millipore-Waters Corp.) at $100 \mathrm{~V}$ for $1 \mathrm{~h}$ and blocked for $1 \mathrm{~h}$ in a buffer containing $5 \%$ fat-free milk in Tris-buffered saline, $0.1 \%$ Tween-20 (TBST). The membranes were then rinsed three times with TBST and incubated overnight at $4{ }^{\circ} \mathrm{C}$ with antibodies diluted in blocking buffer (Go $\alpha$ 1:2000 (polyclonal anti$\mathrm{G}_{\mathrm{o} \alpha}, 551, \mathrm{MBL}$ Int., Woburn, MA, USA), $\alpha$-tubulin 1:400 (sc-8035, Santa Cruz Biotechnology, Inc.)). This Go $\alpha$ antibody cross-reacts with rat and human Go $\alpha$, but it does not bind $\mathrm{G} \alpha \mathrm{i}_{2}$ or $\mathrm{G} \alpha \mathrm{i}_{3}$. Membranes were rinsed three times with TBST and incubated for $1 \mathrm{~h}$ at room temperature with secondary antibodies conjugated to HRP diluted in blocking buffer (goat anti-rabbit 1:5000 (sc-2004, Santa

Table 4 Identification of molecules associated with Go $\alpha 1$ (Q205L) by yeast two-hybrid

\begin{tabular}{|c|c|c|}
\hline Name & $\begin{array}{l}\text { Accession } \\
\text { number }\end{array}$ & $\%$ identity \\
\hline $\begin{array}{l}\text { Intermediate conductance } \\
\text { calcium-activated potassium } \\
\text { channel }\end{array}$ & AF190458 & 95 \\
\hline $\begin{array}{l}\text { Natriuretic peptide precursor } \\
\text { type A (eight clones) }\end{array}$ & NM_012612 & 99 \\
\hline Ankyrin repeat domain 1 & BC072699 & 98 \\
\hline $\begin{array}{l}\text { Myosin, heavy polypeptide } 6 \text {, } \\
\text { cardiac muscle }\end{array}$ & NM_017239 & 94 \\
\hline $\begin{array}{l}\text { Ankyrin repeat domain } 1 \\
\text { (cardiac muscle) }\end{array}$ & NM_013220 & 95 \\
\hline $\begin{array}{l}\text { Actin-binding Rho-activating } \\
\text { protein }\end{array}$ & NM_175844 & 97 \\
\hline Clusterin & BC061534 & 99 \\
\hline $\begin{array}{l}\text { Ubiquitin A-52 residue } \\
\text { ribosomal protein fusion }\end{array}$ & NM_031687 & 99 \\
\hline
\end{tabular}

Published by Bioscientifica Ltd 


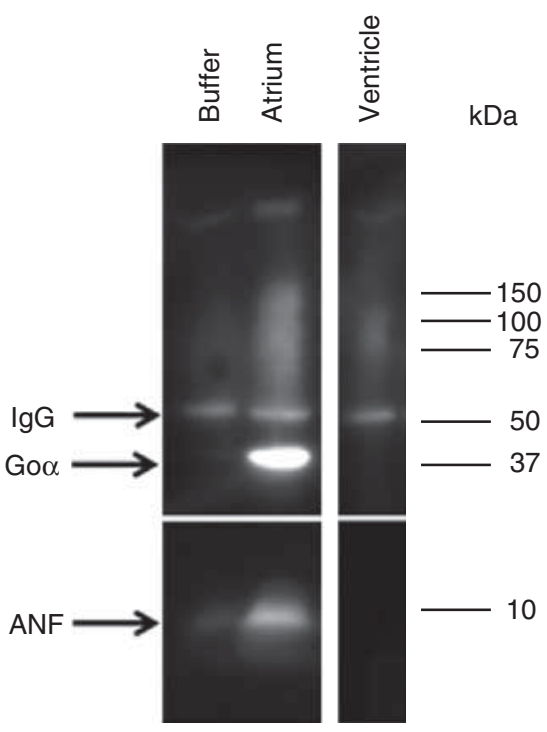

Figure 1

Western blot analysis following electrophoresis of immunoprecipitates from atrial or ventricular homogenates using anti-ANF antibodies.

Cruz Biotechnology, Inc.), goat anti-mouse 1:5000 (1858413, Pierce, Thermo Scientific), and Precision Protein StrepTactin 1:5000 (161-0380, Bio-Rad Laboratories, Inc.)). Membranes were rinsed three times with TBST and were visualized using the FluroChem Alpha Ease ECL imaging system (Alpha Innotech Corp., San Leandro, CA, USA) following enhancement with Luminata Forte chemiluminescene (Millipore-Waters Corp.).

\section{Electron microscopy}

Tissues were finely minced in saline and fixed in Karnovsky's fixative (4\% paraformaldehyde, 5\% glutaraldehyde in $0.2 \mathrm{M}$ phosphate buffer ( $\mathrm{pH} 7.4$ )) overnight; they were then washed three times in washing solution (0.1 M Sorensen's phosphate buffer ( $\mathrm{pH} 7.4), 10 \%$ sucrose, $1 \%$ calcium chloride) and post-fixed in $2 \%$ osmium tetroxide in phosphate buffer. The tissues were then dehydrated in a graded series of alcohols and embedded in Spurr resin. Tissue sections mounted in copper grids were stained with lead citrate and uranyl acetate and then viewed in a JEM-1230 electron microscope. Granule counting was carried out in randomly chosen fields at $3000 \times$ magnification.

\section{NP extraction}

Tissues were extracted in $3 \mathrm{ml}$ of a solution containing $0.1 \mathrm{M} \mathrm{HCl}, 1.0 \mathrm{M}$ acetic acid, and $1 \% \mathrm{NaCl}$ using a Polytron at $70 \%$ power for $15-20 \mathrm{~s}$. The homogenates were centrifuged at $10000 \boldsymbol{g}$ for $30 \mathrm{~min}$ at $4{ }^{\circ} \mathrm{C}$, and the supernatants were processed using Sep-Pak C18 (MilliporeWaters Corp.) cartridges as described in the previous sections, separated into two aliquots, and freeze-dried. The freeze-dried samples were solubilized in either $0.1 \%$ TFA or RIA buffer for HPLC and RIA respectively.

\section{Reverse-phase HPLC}

Reverse-phase HPLC (RP-HPLC) analysis was carried out in a $\mathrm{C}_{18}$ column using a linear gradient elution profile from 15 to $85 \%$ of $80 \% \mathrm{ACN}$ in $0.1 \%$ TFA at $1.5 \mathrm{ml} / \mathrm{min}$ with monitoring at $275 \mathrm{~nm}$ over a total period of $80 \mathrm{~min}$. Fractions were collected every $2 \mathrm{~min}$. One hundred microliters of an aqueous solution of $1 \mathrm{mg} / \mathrm{ml}$ BSA was added to each fraction before it was freeze-dried.

\section{RIA}

RIAs for ANF and BNP were performed as previously described (Sarda et al. 1989, Bensimon et al. 2004).

\section{Immunoprecipitation of Goa/ANF complexes}

Immunoprecipitation of Goa/ANF complexes was carried out in atrial or ventricular homogenates that were obtained by homogenizing $\sim 50 \mathrm{mg}$ of tissue in $0.01 \mathrm{M}$ phosphate buffer ( $\mathrm{pH} 6.5$ ) containing $1 \mu \mathrm{M}$ GDP,

Table 5 ECG parameters in mice. Values are averages of the same time point (1600-1900 h or $0400-0700 \mathrm{~h})$ over 3 days. $n=3$

\begin{tabular}{|c|c|c|c|c|c|c|c|}
\hline Phase/time & Genotype & RR-I (ms) & HR (bpm) & R-amp (mV) & P-amp (mV) & QRS-dur (ms) & PR-I (ms) \\
\hline Rest $1600-1900 \mathrm{~h}$ & Control & 107.4864 & 569.1028 & 0.725167 & 0.087531 & 15.43949 & 34.4616 \\
\hline Rest $1600-1900 \mathrm{~h}$ & $\mathrm{cGo} \alpha-1-$ & 106.8187 & 572.3695 & 0.852373 & 0.076315 & 14.30988 & 33.22616 \\
\hline Awake 0400-0700 h & Control & 107.071 & 576.5367 & 0.735165 & 0.083329 & 15.08417 & 33.66375 \\
\hline Awake 0400-0700 h & $\mathrm{cGo} \alpha-/-$ & 106.3489 & 576.0036 & 0.84694 & 0.079072 & 14.34907 & 33.42748 \\
\hline
\end{tabular}

RR-I, interval between R waves; HR, heart rate; R-amp, amplitude of the R wave; P-amp, amplitude of the P wave; QRS-dur, duration of the QRS complex; PR-I, interval between the $\mathrm{P}$ wave and the $\mathrm{R}$ wave.

http://jme.endocrinology-journals.org DOI: 10.1530/JME-15-0081
(C) 2015 Society for Endocrinology Printed in Great Britain
Published by Bioscientifica Ltd 


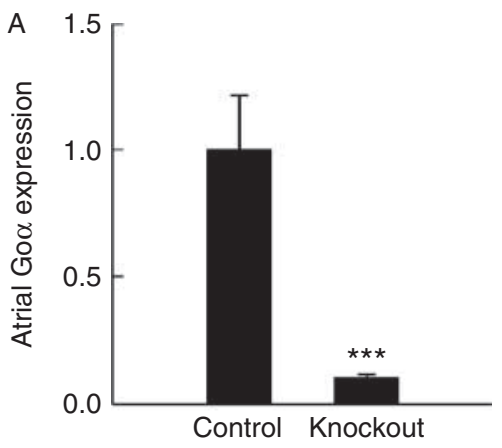

B

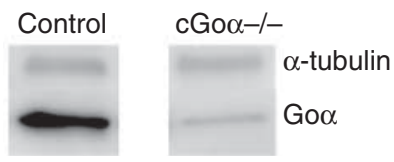

Figure 2

(A) mRNA expression levels of Go $\alpha$ in control and $\mathrm{CGo} \alpha-/-$ genotypes through RT-PCR. Values are means \pm S.E.M.; $n=6 ; * * * P<0.001$. (B) Protein expression of Go $\alpha$ in atrial tissue. Western blot analysis using a specific Go $\alpha$ polyclonal antibody in control and $\mathrm{cGo} \alpha-/-$ mice. Representative band of $n=4$.

$30 \mu \mathrm{M} \mathrm{AlF}-(30 \mu \mathrm{M} \mathrm{AlCl}, 1.2 \mathrm{mM} \mathrm{NaF}), 6 \mathrm{mM} \mathrm{MgCl}_{2}$, and $1 \% \mathrm{NaCl}$. Following centrifugation, the pellet was re-homogenized, and the supernatants were combined. After incubation overnight with $1 \mu$ l of undiluted ANF antibody, $20 \mu$ l of Protein A/G Plus Agarose (Santa Cruz Biotechnology, Inc.) were added and mixed by inversion for $1 \mathrm{~h}$ at $4{ }^{\circ} \mathrm{C}$. Following centrifugation at $400 \mathrm{~g}$ for 30-60 s, the resulting pellet was washed twice with $0.01 \mathrm{M}$ phosphate buffer containing $1 \mu \mathrm{M}$ GDP, $30 \mu \mathrm{M} \mathrm{AlF} \mathrm{Al}_{4}^{-}$, $6 \mathrm{mM} \mathrm{MgCl}_{2}$, and $1 \% \mathrm{NaCl}$. Electrophoretic separation of samples and western blotting was carried out as described above. Go $\alpha$ (polyclonal anti-G $\mathrm{o}_{\alpha}, 551, \mathrm{MBL}$ Int.) and ANF RyB8 antibody (an ANF-specific polyclonal antibody produced in our laboratory) were used at a concentration of 1:1333 and 1:2000 respectively. This Go $\alpha$ antibody cross-reacts with rat and human Go $\alpha$, but it does not bind Gi2 $\alpha$ and Gi3 $\alpha$.

\section{Electrocardiography}

ECG transmitters (ETA-F20, Data Science International, San Paul, MN, USA) were implanted in mice pretreated with s.c. buprenorphine $(0.05 \mathrm{mg} / \mathrm{kg})$ and anesthetized with isoflurane $(1.5-2 \%)$. A $2-3 \mathrm{~cm}$ midline abdominal incision was made, and the telemetry unit was placed within the abdominal cavity. Telemetry data gathering began on post-surgery day 3 using the software supplied with the telemetry unit.

\section{Statistical analysis}

Data are reported as means \pm s.E.M. Student's $t$-tests were performed to determine statistical significance between groups. $P \leq 0.05$ was considered significant.

\section{Results}

\section{Yeast two-hybrid and co-immunoprecipitation}

To determine whether the previously observed microscopic co-localization of Go $\alpha$ and ANF could reflect protein-protein interaction at the cellular level, twohybrid and co-immunoprecipitation studies were conducted. Screening of a rat atrial cDNA library with a mutationally active form of Goo1 (Q205L) identified several cDNA clones of interest, including eight clones that contained open reading frames corresponding to proANF. No clones containing BNP sequences were found, and only single clones were detected for the other species listed in Table 4.

Immunoprecipitation of atrial tissue homogenates using anti-ANF antibodies produced complexes that upon electrophoretic and western blot analysis yielded bands consistent with protein-protein interaction between Go $\alpha$ and ANF. Immunoprecipitates isolated from ventricular tissue homogenates did not reveal bands for either ANF or Go $\alpha$ (Fig. 1).

These results support the view that activated forms of Go $\alpha$ and ANF interact to form a complex in vivo (Table 5).

\section{Cardiac Go $\alpha$ knockout}

Given the association between Go $\alpha$ and ANF that was found by yeast two-hybrid and co-immunoprecipitation,

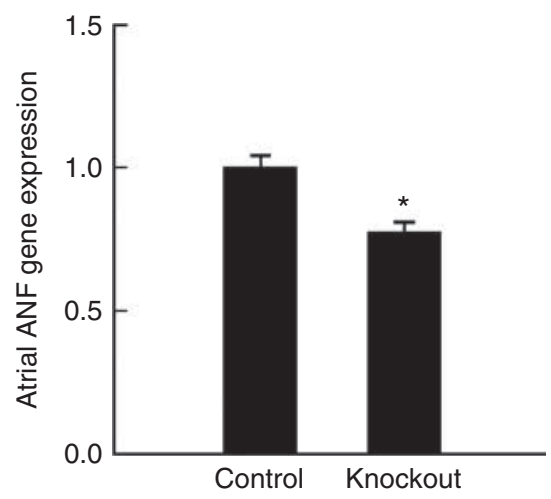

Figure 3

ANF relative expression levels in atrial tissue. Expression levels of ANF in control and $\mathrm{CGo} \alpha-I-$ genotypes. Values are means \pm s.E.M.; $n=6$; ${ }^{*} P<0.05$.

Published by Bioscientifica Ltd 


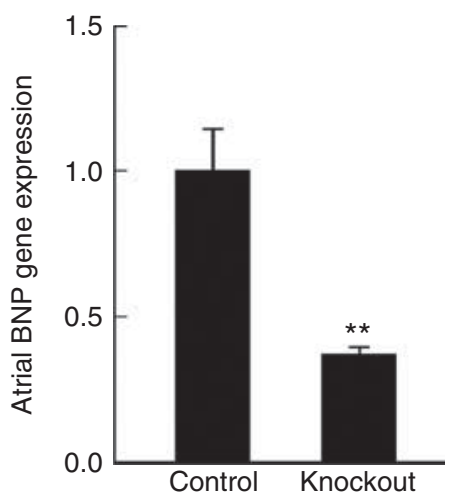

Figure 4

BNP relative expression levels in atrial tissue. Expression levels of BNP in control and $\mathrm{CGo} \alpha-/-$ genotypes. Values are means \pm s.E.M.; $n=6$; $* * P<0.01$.

we examined the role of Go $\alpha$ in atrial cardiomyocyte phenotype using a conditional Go $\alpha$-floxed mouse in which two loxP sites exist in both alleles flanking the fifth and sixth exons common to the two variants (Go 1 and Go $\alpha 2$ ). By expressing Cre, the loxP sites recombine to delete the fifth and sixth exons of Go $\alpha$, which thereby produces a truncated mRNA sequence and deletes the C-terminal functional amino acids (Jiang et al. 1997, Chamero et al. 2011). The N-terminus of Go $\alpha$ lacks the functional binding domains to its signaling pathways with adenylyl-cyclase and phospholipase $\mathrm{C}$ as well as its binding to the $\mathrm{G} \beta \gamma$ complex (Birnbaumer 2007, Zhao et al. 2010).

Through the standard breeding of Go $\alpha$-floxed mice and $\alpha$-MHC-Cre mice, heart-specific conditional Go $\alpha$ knockout mice were derived after two generations of mating. Continuous breeding of $\alpha$-MHC-Cre mice to Go $\alpha$-floxed mice produced six genotypes of mice (Table 1). No Cre toxicity was observed in these mice (Baba et al. 2005), because no two animals expressing $\alpha$-MHC-Cre were mated.

Genotyping of tail, ventricular, or atrial tissue using Go $\alpha$-floxed primers to distinguish between the WT, heterozygous, and homozygous Go $\alpha$-floxed and Go $\alpha$ deleted genotypes showed a $2142 \mathrm{bp}$ PCR product that represented the Go $\alpha$ allele and contained two loxP sites in the Go $\alpha$ gene (Go $\alpha$-floxed alleles), an 1868 bp PCR product that represented the Go $\alpha$ WT allele, and a 442 bp PCR product that represented the Go $\alpha$ allele after recombination by Cre recombinase, which had thereby produced a deleted allele and truncated band.

Genotyping of tail, ventricular, and atrial tissue using $\alpha$-MHC-Cre primers to distinguish between the mice carrying the Cre enzyme and those without the Cre enzyme showed a $300 \mathrm{bp}$ PCR product that represented the presence of Cre in the genome (one Cre allele) and a 200 bp PCR product that represented the internal control in a sample without the presence of Cre.

\section{Go $\alpha$, NP, and ChgA mRNA and protein expression}

In the atria of $\mathrm{cGo} \alpha-/-$ mice, Go $\alpha$ mRNA was reduced by $90 \%(P<0.001)$ as compared to control mice (Fig. $2 \mathrm{~A})$. In line with these results, Go $\alpha$ protein expression was much less abundant in the atria of $\operatorname{cGo} \alpha-/-$ mice as compared to control mice (Fig. 2B). ANF was knocked down by $23 \%$ in the atria of $\mathrm{cGo} \alpha-/-$ mice as compared to controls $(P<0.05$; Fig. 3$)$. BNP had a more significant reduction in expression (63\%) than ANF did $(P<0.01$; Fig. 4).

ChgA knockout mice did not show any changes in either ANF or BNP transcript levels in the atria (data not shown).

The quantitation of peptide content by RIA in atrial tissue extracts of control and $\mathrm{cGo} \alpha-/-$ mice showed that the atrial ANF content in cGo $\alpha-/-$ mice (16 489 pg/mg of tissue) was not statistically different from that in control mice (18 $546 \mathrm{pg} / \mathrm{mg}$ of tissue) (Fig. 5). Tissue BNP content was significantly lower in the atria of $\mathrm{cGo} \alpha-/-$ mice. Control mice had an average BNP concentration of $118 \mathrm{pg} / \mathrm{mg}$ of tissue, whereas the $\mathrm{cGo} \alpha-/-$ mice had an average BNP concentration of $84 \mathrm{pg} / \mathrm{mg}$ of tissue $(P<0.05)$ (Fig. 6). ChgA knockout mice did not show any changes in either ANF or BNP peptide levels in the atria or plasma (data not shown).

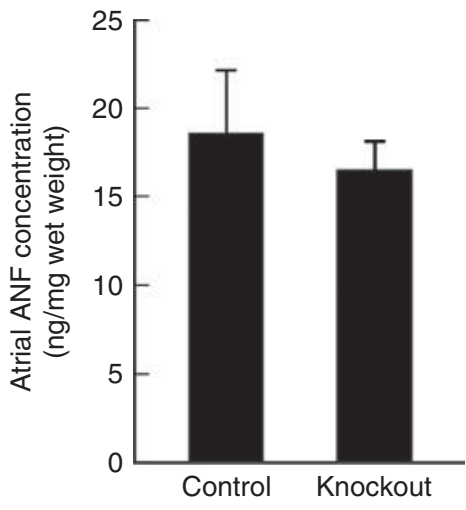

Figure 5

Concentration of ANF peptide in atrial tissue. Values are means \pm S.E.M.; $n=6$.

Published by Bioscientifica Ltd. 


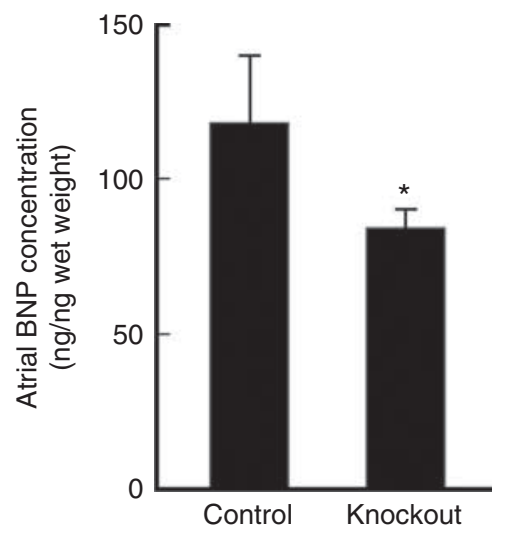

Figure 6

Concentration of BNP peptide in atrial tissue. Values are means \pm s.E.M.; $n=6 ; * P<0.05$.

\section{HPLC analysis of ANF tissue stores}

Molecular forms of intracellular ANF in atrial tissue extracts were examined by RP-HPLC to determine the ratio content of low molecular weight processed ANF $\left(\mathrm{ANF}_{99-126}\right)$ and high molecular weight proANF $\left(\mathrm{ANF}_{1-126}\right)$. RP-HPLC profiles showed the presence of both forms of ANF in each genotype, with similar ratios of proANF to processed ANF (Fig. 7A and B).

\section{ANF peptide content in plasma}

Plasma ANF concentration did not differ between cGo $\alpha-/-$ mice and control mice (Fig. 8). BNP plasma level concentration was below assay sensitivity for normal and transgenic animals.

\section{Microscopy}

Figure 9A and B shows medium-power images of atrial cardiomyocytes by conventional transmission electron microscopy. The general morphological features of both transgenic and control atrial cardiomyocytes did not show obvious morphological differences except for an apparent loss of electron density in the atrial granule's core in transgenic animals (Fig. 9B). However, even by simple inspection, it was obvious that cardiomyocytes of the Go $\alpha-/-$ mice contained fewer granules than the controls did. Quantification of the number of granules per square micron of tissue section from Go $\alpha$ conditional knockouts showed a near halving in the number of granules as compared to controls (Fig. 10).

\section{Electrocardiography}

In order to determine differences in the electrical conductance of $\mathrm{cGo} \alpha-/-$ mice, telemetry recordings were obtained via an implantable telemetry unit. A 3-day continuous recording period was carried out in three mice per genotype during daytime hours (at rest) and during nighttime hours (while awake). The parameters analyzed in these mice included RR intervals, heart rate, R-wave amplitude, P-wave amplitude, QRS duration, P-wave duration, and PR interval. Both genotypes had similar recordings, and none of the aforementioned parameters was significantly different in the $\operatorname{cGo} \alpha-/-$ mice as compared to the control mice (Table 3). An ECG tracing that represents four cardiac cycles is shown in Fig. 11.

\section{Discussion}

The present study was designed to determine the role of the Go protein $\alpha$ subunit Go $\alpha$ in determining atrial cardiomyocyte phenotype, given previous indications that it is involved with atrial secretory granules and with ANF secretion. Generally, heterotrimeric G proteins are associated with secretory granule biogenesis in other
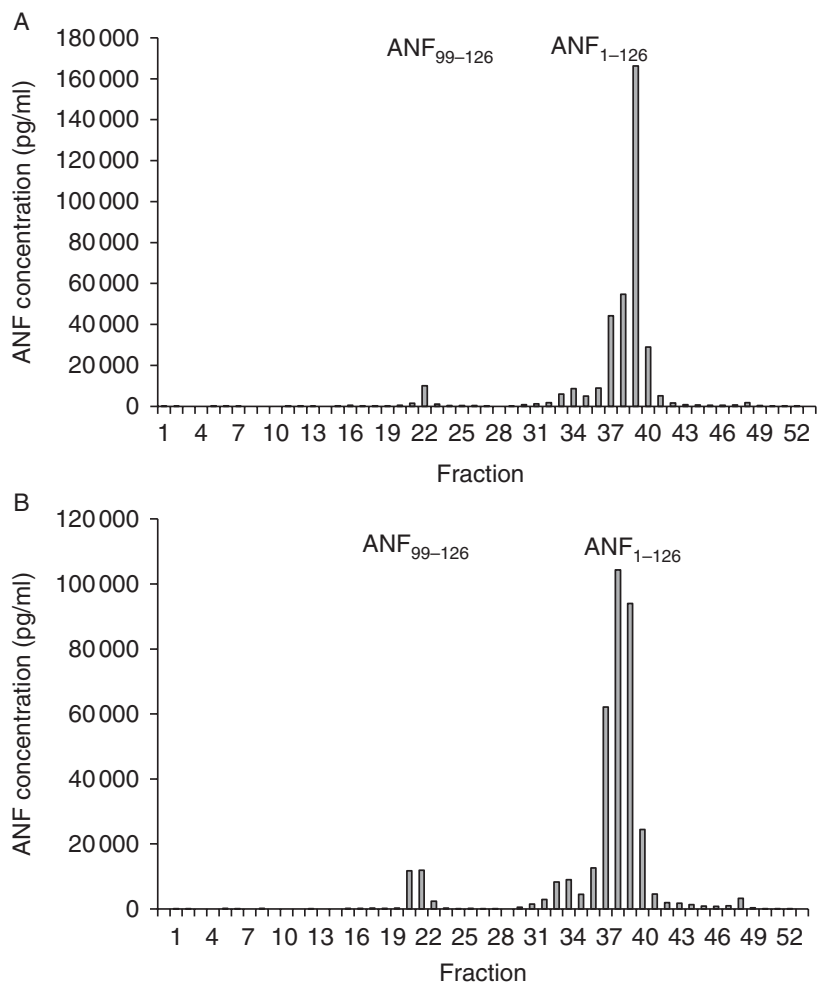

Figure 7

RP-HPLC profiles of atrial tissue ANF in (A) control mice and (B) cGo $\alpha-/-$.

Published by Bioscientifica Ltd. 


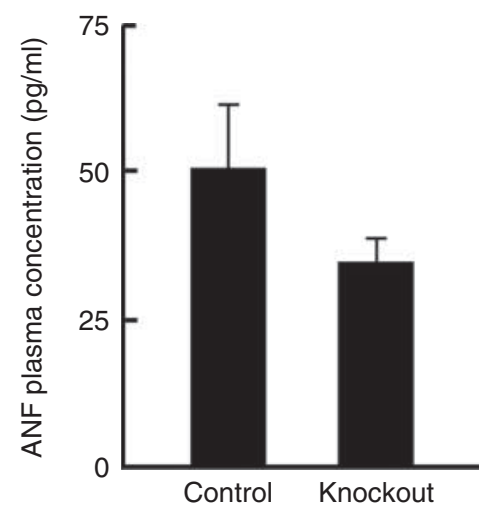

Figure 8

ANF concentration in plasma of control or $\mathrm{CGo} \alpha-/-$ genotypes. Values are means \pm s.E.M.; $n=4$ for control; $n=5$ for $\mathrm{CGo} \alpha-I-$.

endocrine organs (Barr et al. 1991, Burgoyne \& Morgan 1993, Gasman et al. 1997). The Go $\alpha$ subunit has been implicated in various parts of this pathway (Zhao et al. 2010). Far greater amounts of Go $\alpha$ are found within the atria of the heart as compared to the ventricles (Eschenhagen et al. 1995). In addition, G proteins such as Go, are stretch-sensitive (Van Wagoner 1993), and they are involved in several secretory processes, including ANF secretion, together with $\mathrm{K}^{+}$channels (Ogawa et al. 2009). Both light and electron microscopy immunocytochemistry have shown that Go $\alpha$ co-localizes in atrial granules with ANF with a preferential distribution in the granule membrane (Wolf et al. 1998, Bensimon et al. 2004, Muth et al. 2004). The bulk of ventricular cardiomyocytes do not display Go $\alpha$ immunoreactivity.

An additional indication of Gi/o involvement in ANF secretion is the fact that PTX can completely abolish stretch-secretion coupling (Kuroski de Bold \& de Bold 1991, Bensimon et al. 2004). Finally, a comparison of gene expression profiles using oligonucleotide arrays has shown a uniquely high expression of Go $\alpha 1$ in the atria (McGrath $\&$ de Bold 2009). The results in the present study, which were obtained by yeast two-hybrid and immunoprecipitation techniques further suggest an association between ANF and Go $\alpha$.

ANF exists in the form of proANF within atrial secretory granules. The latter appears to play a master regulatory role in the formation of secretory granules, as is suggested by the fact that ANF knockout mice lack secretory granules (John et al. 1995, Dikeakos \& Reudelhuber 2007). Given the association of ANF with Go $\alpha$, it is reasonable to postulate a sorting role for membranebound Go $\alpha$ during granule maturation, a model that was proposed by Arvan \& Halban (2004). This model, which was denominated 'sorting by retention', suggests that proteins within secretory vesicles (e.g., proANF) that arise from the TGN and are destined to be secreted by a regulatory mechanism are retained in secretory granules (e.g., by interaction with Go $\alpha$ ), whereas other proteins are sorted into other compartments, such as lysosomes or endosomes.

In all, these previous studies do not provide a clear view of how Go $\alpha$ participates in the biogenesis of
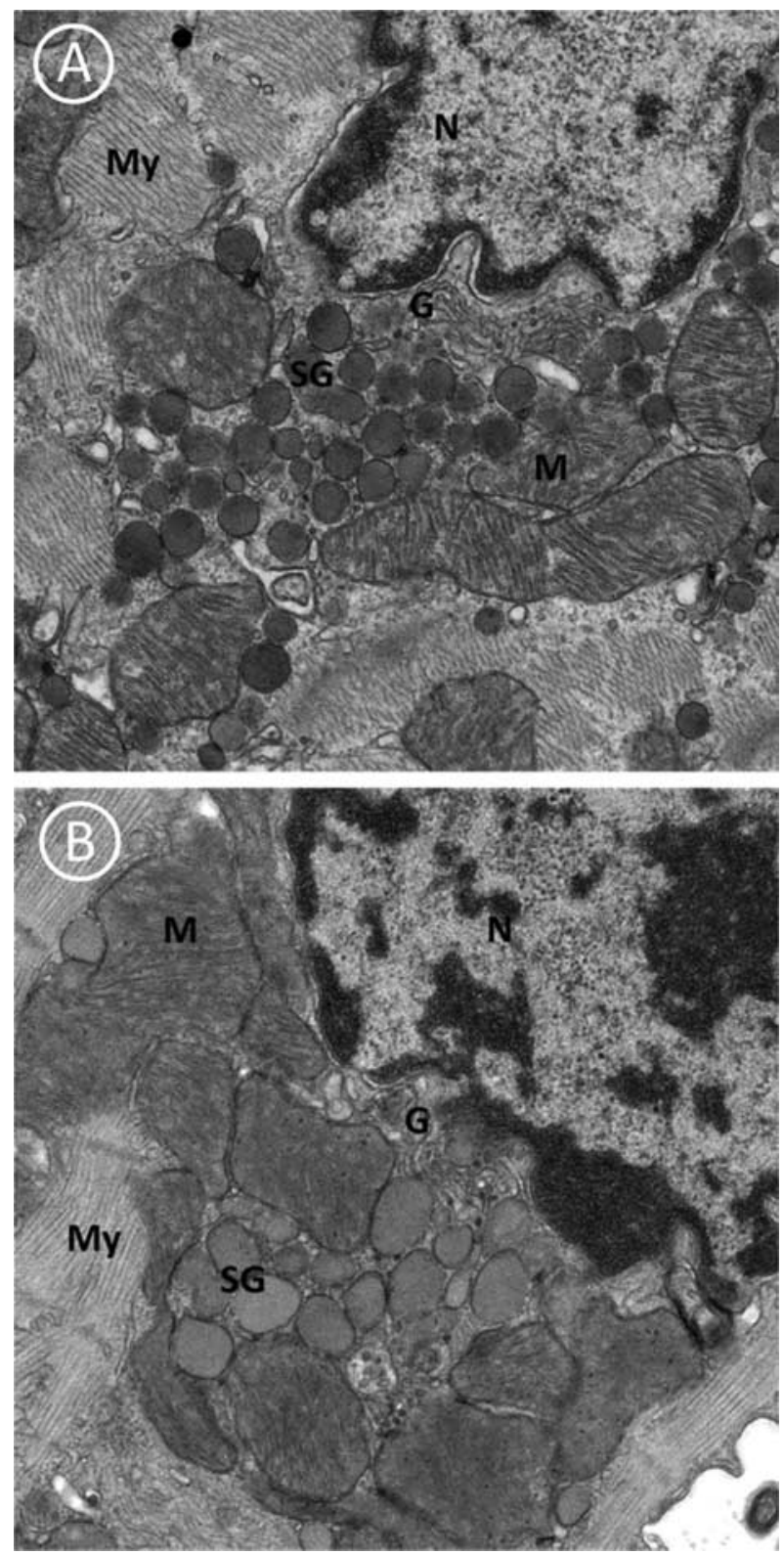

\section{Figure 9}

Electron microscopy images of atrial cardiomyocytes. Atrial muscle cell in control mice (A) and CGo $\alpha-/$ - mice (B). SG, secretory granules; G, Golgi complex; N, nucleus; $M$, mitochondria; My, myofibrils. Magnification 5000×. 


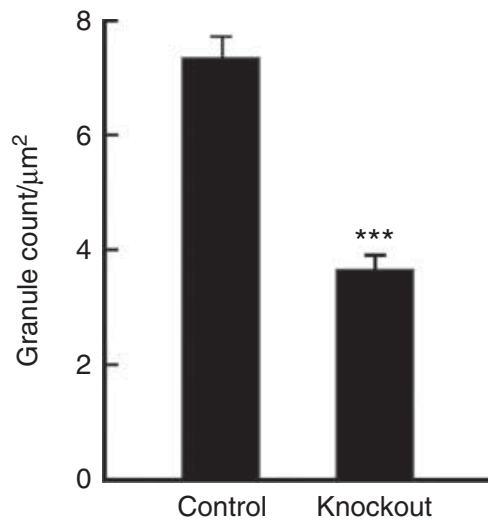

\section{Figure 10}

Specific atrial granule density in atrial cardiomyocytes. $n$ per group $=3$ animals/genotype $\times 2$ blocks/animal $\times 1$ section/block $\times 95$ or 98 fields/ section for control or $\mathrm{CGo} \alpha-/-$ mice respectively. Values are means \pm s.E.M.; $* * * P<0.001$.

ANF-containing granules. Therefore, we postulated that the suppression of Go $\alpha$ expression would contribute information in this respect. A complication in taking this approach is that the homologous recombinant knockout for the Gnao1 gene induces severe neurological complications and very early lethality (Jiang et al. 1997). For this reason, we generated a conditional, heart-specific knockout of Go $\alpha$ in mice according to published breeding protocols for Cre/lox mice (Niu et al. 2005). In the present study, heart-specific Go $\alpha$ knockout mice were produced in Mendelian frequencies without any severe motor or neurological symptoms nor any gross morphological features in the heart associated with this deletion. These mice appeared normal and lived into adulthood.

The yeast two-hybrid experiments and the immunoprecipitation studies carried out as part of the present investigation clearly show an association of Go $\alpha$ with ANF in a fashion that suggests that Go $\alpha$ plays a role in proANF sorting into storage vesicles, which is in accordance with the sorting by retention model proposed by Arvan \& Halban (2004).

No protein-protein interaction was detected between BNP and Go $\alpha$, but atrial stores of BNP nonetheless decreased. The finding that BNP deceased more significantly than ANF did may reflect the fact that the determination of ANF introduces a larger variance than the determination of BNP does because of the large dilutions required to perform the RIA. Nevertheless, the finding suggests that a mechanism exists to keep the molecular ratios of these two hormones constant within the storage granules. A second suggestion brought about by the present observations is that the association between
proANF and Go $\alpha$ protects the former molecule but not BNP from proteolytic processing, which thus explains why the storage forms of NP in the atria consist of proANF and processed BNP. In addition, the fact that Chga expression was not affected in the knockouts suggests that Go $\alpha$ function is restricted to the NP.

We have previously reported on the relationship between ANF secretion, $\mathrm{K}^{+}$channels, and Go $\alpha$ based on evidence obtained through oligonucleotide array analysis and yeast two-hybrid analysis (McGrath \& de Bold 2009, Ogawa et al. 2009). Pharmacological interventions with drugs known to pharmacologically affect the function of specific $\mathrm{K}^{+}$channels, including adenosine triphosphatesensitive $\mathrm{K}^{+}$channels, TWIK-related $\mathrm{K}^{+}$channel-1 (TREK-1), and the $\mathrm{Ca}^{2+}$-activated intermediate conductance $\mathrm{K}^{+}$ channel (SK4) modified ANF secretion to various extents. SK4 was expressed specifically in the atria, and the yeast two-hybrid analysis specifically demonstrated an interaction of this channel with Go $\alpha$. However, in the present investigation, we found no changes in cardiac electrophysiological activity in $\mathrm{cGo} \alpha-/-$ animals.

The most notable phenotypic change that was observed in atrial cardiomyocytes of Go $\alpha-/-$ animals was a loss of electron density of the granule's core and
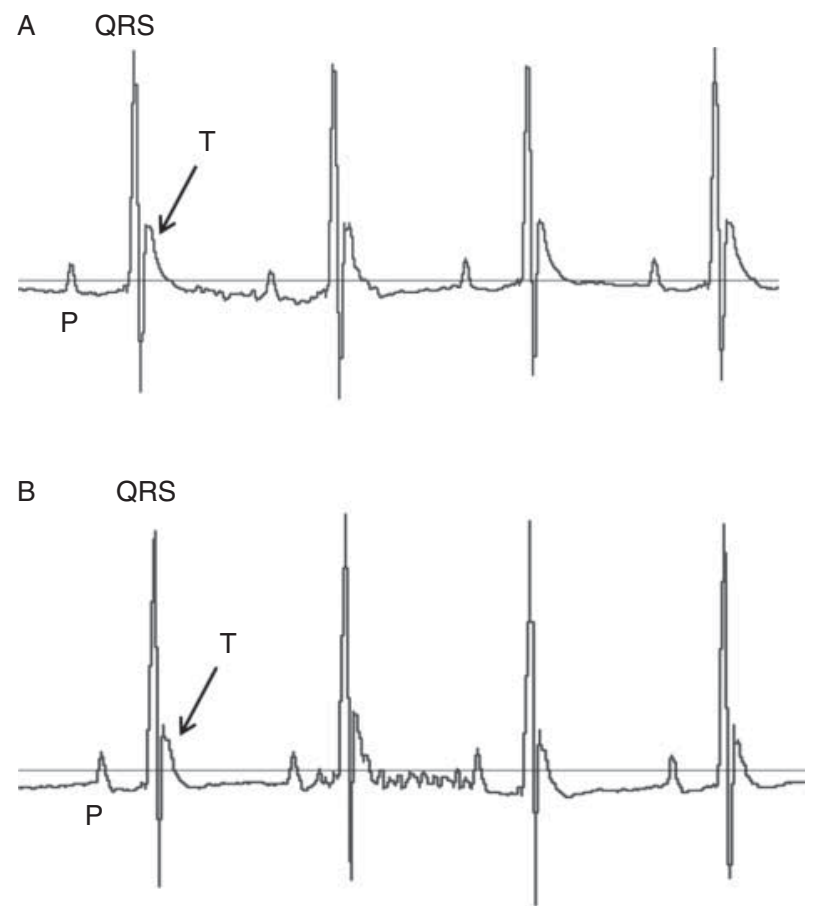

Figure 11

ECG tracings of four cardiac cycles in mice. Four cardiac cycles are shown in control mice (A) and cGo $\alpha-/-$ mice (B). P, P wave; Q, Q wave; R, R wave; S, S wave. $n=3$.

Published by Bioscientifica Ltd. 
a significant reduction in the number of granules. The conditional Go $\alpha$ deletion led to a $90 \%$ loss of Go $\alpha$ mRNA, so these mice had an average $10 \%$ genetic expression of Go $\alpha$, which was reflected by the small but significant amount of Go $\alpha$ protein evident in the western blots. This remaining protein likely represents cells in which Creinduced deletion may not have been completed on both chromosomes.

Whether a total deletion would have led to a complete disruption of the formation of granules cannot be determined from the present investigations. Together with the changes in phenotype revealed by electron microscopy, it was evident that both ANF and BNP atrial content decreased (albeit not significantly for ANF) in the transgenic animals. That stored ANF content would diminish alongside a decrease in its interacting partner, Go $\alpha$, was not surprising, but the significant decrease in BNP was not expected, and it hints at a mechanism that preserves a predefined molar relationship of stored NP in both normal and transgenic hearts.

The present investigation was designed to determine cardiomyocyte secretory phenotype changes rather than changes in the contractile phenotype, cardiac function, or other parameters in the animal as a whole. Therefore, we did not attempt to determine if the knockout had wholeanimal consequences (e.g., effects on blood pressure, cardiac remodeling, etc.). This point should be addressed in future investigations.

Go $\alpha$ regulates insulin granule dynamics by acting as a repressor and inhibitor of vesicular docking in pancreatic $\beta$ cells during normal physiological functions (Zhao et al. 2010). In pancreatic-specific conditional Go $\alpha$ knockout mice, $35-100 \%$ more insulin vesicles are docked at the plasma membrane as compared to control $\beta$ cells (Zhao et al. 2010). Therefore, in the pancreatic $\beta$-cell model, Go $\alpha$ acts as a key regulator of granule docking by interacting at either the docking or the priming station of cells to prevent the oversecretion of insulin (Zhao et al. 2010). In chromaffin cells, Go $\alpha$ inhibits granule fusion to the plasma membrane by controlling the priming of granules, which therefore regulates catecholamine secretion (Gasman et al. 1997). The most prominent result from the present study was the $51 \%$ significant decrease in granule numbers and changes in the electron density of the granules in cGo $\alpha-/-$ mice as compared to control mice. A finding similar to this was not reported in the previous studies on $\beta$ cells or chromaffin cells, which suggests that either Go $\alpha$ plays various roles in the vectorial transport of secretory products within secretory cells or that it plays different roles in different cell types.
Declaration of interest

The authors declare that there is no conflict of interest that could be perceived as prejudicing the impartiality of the research reported.

\section{Funding}

This work was supported by the Heart and Stroke Foundation of Ontario (grant number NA 6992).

\section{References}

Arvan P \& Halban PA 2004 Sorting ourselves out: seeking consensus on trafficking in the beta-cell. Traffic 5 53-61. (doi:10.1111/j.1600-0854. 2004.00152.x)

Baba Y, Nakano M, Yamada Y, Saito I \& Kanegae Y 2005 Practical range of effective dose for Cre recombinase-expressing recombinant adenovirus without cell toxicity in mammalian cells. Microbiology and Immunology 49 559-570. (doi:10.1111/j.1348-0421.2005.tb03753.x)

Barr FA, Leyte A, Mollner S, Pfeuffer T, Tooze SA \& Huttner WB 1991 Trimeric G-proteins of the trans-Golgi network are involved in the formation of constitutive secretory vesicles and immature secretory granules. FEBS Letters 294 239-243. (doi:10.1016/0014-5793(91)81438-E)

Bensimon M, Chang A, Kuroski-de Bold ML, Ponce A, Carreras D \& de Bold AJ 2004 Participation of $\mathrm{G}$ proteins in natriuretic peptide hormone secretion from heart atria. Endocrinology 145 5313-5321. (doi:10.1210/ en.2004-0698)

Birnbaumer L 2007 Expansion of signal transduction by G proteins. The second 15 years or so: from 3 to 16 alpha subunits plus betagamma dimers. Biochimica et Biophysica Acta 1768 772-793. (doi:10.1016/ j.bbamem.2006.12.002)

Burgoyne RD \& Morgan A 1993 Regulated exocytosis. Biochemical Journal 293 305-316.

Chamero P, Katsoulidou V, Hendrix P, Bufe B, Roberts R, Matsunami H, Abramowitz J, Birnbaumer L, Zufall F \& Leinders-Zufall T $2011 \mathrm{G}$ protein $\mathrm{G}($ alpha)o is essential for vomeronasal function and aggressive behavior in mice. PNAS 108 12898-12903. (doi:10.1073/pnas. 1107770108)

Dikeakos JD \& Reudelhuber TL 2007 Sending proteins to dense core secretory granules: still a lot to sort out. Journal of Cell Biology $\mathbf{1 7 7}$ 191-196. (doi:10.1083/jcb.200701024)

Eschenhagen T, Laufs U, Schmitz W, Scholz H, Warnholtz A, Weil J \& Schafer H-J 1995 Enrichment of G protein $\alpha$-subunit mRNAs in the AV-conducting system of the mammalian heart. Journal of Molecular and Cellular Cardiology 27 2249-2263. (doi:10.1016/S0022-2828 (95)91659-8)

Gasman S, Chasserot-Golaz S, Popoff MR, Aunis D \& Bader MF 1997 Trimeric $\mathrm{G}$ proteins control exocytosis in chromaffin cells. Go regulates the peripheral actin network and catecholamine secretion by a mechanism involving the small GTP-binding protein Rho. Journal of Biological Chemistry 272 20564-20571. (doi:10.1074/jbc.272.33.20564)

Hendy GN, Li T, Girard M, Feldstein RC, Mulay S, Desjardins R, Day R, Karaplis AC, Tremblay ML \& Canaff L 2006 Targeted ablation of the chromogranin a (Chga) gene: normal neuroendocrine dense-core secretory granules and increased expression of other granins. Molecular Endocrinology 20 1935-1947. (doi:10.1210/me.2005-0398)

Jiang M, Boulay G, Spicher K, Peyton MJ, Brabet P, Birnbaumer L \& Rudolph U 1997 Inactivation of the G alpha 12 and $\mathrm{G}$ alpha o genes by homologous recombination. Receptors \& Channels 5 187-192.

John SW, Krege JH, Oliver PM, Hagaman JR, Hodgin JB, Pang SC, Flynn TG \& Smithies O 1995 Genetic decreases in atrial natriuretic peptide and salt-sensitive hypertension. Science 267 679-681. (doi:10.1126/science. 7839143)

Published by Bioscientifica Ltd. 
Kuroski de Bold ML \& de Bold AJ 1991 Stretch-secretion coupling in atrial cardiocytes. Dissociation between atrial natriuretic factor release and mechanical activity. Hypertension 18 III-169-III-178. (doi:10.1161/01. HYP.18.5_Suppl.III169)

Mangat H \& de Bold AJ 1993 Stretch-induced atrial natriuretic factor release utilizes a rapidly depleting pool of newly synthesized hormone. Endocrinology 133 1398-1403. (doi:10.1210/endo.133.3.8365374)

McGrath MF \& de Bold AJ 2005 Determinants of natriuretic peptide gene expression. Peptides 26 933-943. (doi:10.1016/j.peptides. 2004.12.022)

McGrath MF \& de Bold AJ 2009 Transcriptional analysis of the mammalian heart with special reference to its endocrine function. BMC Genomics $\mathbf{1 0}$ 254. (doi:10.1186/1471-2164-10-254)

Muth E, Driscoll WJ, Smalstig A, Goping G \& Mueller GP 2004 Proteomic analysis of rat atrial secretory granules: a platform for testable hypotheses. Biochimica et Biophysica Acta 1699 263-275. (doi:10.1016/ j.bbapap.2004.03.007)

Niu Z, Yu W, Zhang SX, Barron M, Belaguli NS, Schneider MD, Parmacek M, Nordheim A \& Schwartz RJ 2005 Conditional mutagenesis of the murine serum response factor gene blocks cardiogenesis and the transcription of downstream gene targets. Journal of Biological Chemistry 280 32531-32538. (doi:10.1074/jbc.M501372200)
Ogawa T, Vatta M, Bruneau BG \& de Bold AJ 1999 Characterization of natriuretic peptide production by adult heart atria. American Journal of Physiology. Heart and Circulatory Physiology 276 H1977-H1986.

Ogawa T, Forero McGrath M, Burgon PG, Kuroski de Bold ML, Georgalis T \& de Bold AJ 2009 Role of potassium channels in stretch-promoted atrial natriuretic factor secretion. Journal of the American Society of Hypertension 3 9-18. (doi:10.1016/j.jash.2008.07.002)

Sarda IR, de Bold ML \& de Bold AJ 1989 Optimization of atrial natriuretic factor radioimmunoassay. Clinical Biochemistry 22 11-15. (doi:10.1016/ S0009-9120(89)80063-3)

Van Wagoner DR 1993 Mechanosensitive gating of atrial ATP-sensitive potassium channels. Circulation Research 72 973-983. (doi:10.1161/01. RES.72.5.973)

Wolf WP, Spicher K, Haase H \& Schulze W 1998 Immunocytochemical localization of the G-protein sub-unit, $\mathrm{G}(\mathrm{o})$ alpha, in rat heart. Implications for a role of $\mathrm{G}(\mathrm{o})$ alpha in secretion of cardiac hormones. Journal of Molecular and Cellular Cardiology 30 1149-1162. (doi:10.1006/ jmcc.1998.0679)

Zhao A, Ohara-Imaizumi M, Brissova M, Benniger RK, Xu Y, Hao Y, Abramowitz J, Boulay G, Powers AC, Piston D et al. 2010 Gao represses insulin secretion by reducing vesicular docking in pancreatic $\beta$ cells. Diabetes 59 2522-2529. (doi:10.2337/db09-1719)

Received in final form 15 April 2015

Accepted 24 April 2015

Accepted Preprint published online 27 April 2015 http://jme.endocrinology-journals.org DOI: $10.1530 / \mathrm{JME}-15-0081$
(C) 2015 Society for Endocrinology Printed in Great Britain
Published by Bioscientifica Ltd. 